\title{
PROXIMATE AND MICRONUTRIENT COMPOSITIONS OF FOUR DIFFERENT CULTIVARS OF AUBERGINE (Solanum melongena)
}

\author{
Ebiringa, D. C. \\ Department of Food Science and Technology, Imo State University, Owerri, Nigeria. \\ E-mail:danchidozie@yahoo.com
}

\begin{abstract}
Aubergine or Garden egg is a vegetable commonly chewed as such and served as kolanut within the southeast part of Nigeria. The aim of the study is to determine the proximate and micronutrient compositions of four different cultivars of aubergine (Solanum melongena). Four cultivars of aubergine, namely Solanum anguivi - A, Solanum aethiopicum (gilo group) - B, Solanum macrocarpon - $C$, and Solanum aethiopicum (kumba group) - D, were purchased from the Eke-ukwu market in Owerri, Imo State, Nigeria. Proximate compositions were determined using the standard AOAC methods. Mineral determination was carried out by using methods incorporating wet digestion while Vitamins were determined by using specific methods appropriate for each vitamin. The proximate analysis results of the samples showed that moisture content ranged from $80.29 \%$ for sample $C$ to $90.63 \%$ for sample B; fat ranged from 1.40 (sample A) to 4.00 (sample C); Ash: 0.52 - $0.76(C-A)$; Protein: $3.94-8.31(A-C)$; Crude fibre: $2.02-2.86(C-A)$; Carbohydrate: $0.47-4.86(B-C)$. The micro-nutrient compositions showed that vitamin A ranged from 475.18i.u. (sample B) to 528.06i.u. (sample A); Vitamin C: 908.6 - $2929.65 \mathrm{mg} / 100 \mathrm{~g}(A-C)$; Calcium: 97.95 - 586.02ppm (D - A); Magnesium: 80.63 - 106.31ppm (B-A); Iron: $10.14-14.97 \mathrm{ppm}(C-A)$. The four cultivars of aubergine contained fair amounts of macronutrients in addition to the substantial amounts of micronutrients. In all, Solanum anguivi cultivar was the richest of the four in nutrient compositions, and, therefore, the most preferred.
\end{abstract}

Keywords : Aubergine, eggplant, cultivars, nutrient, compositions

https://dx.doi.org/10.4314/jafs.v18i2.10

\section{INTRODUCTION}

Aubergine (Solanum melongena) also known as egg plant or garden egg is called guata in Hausa, afufa or anara in Igbo and Igbagba in Yoruba. It belongs to the family of Solanaceae or Nightshade. The Eggplant is an annual herb that produces a large shaped berry varying in colour from dark purple to red with yellow, green or sometimes white stripes (Onimawo, 2002). The tropical cultivars of eggplant such as Solanum anguivi, Solanum aethiopicum (gilo group), S. macrocarpon and S. aethiopicum (kumba group) are commonly found in all seasons in Nigeria,

Journal of the Faculty of Agriculture and Veterinary Medicine, Imo State University Owerri website: www ajol.info; Attribution: Non-commercial CC BY-NC: CC-BY-NC 
West Africa (Nwannaet., al, 2019). This fruit is full of wonders; it can be eaten as fresh whole vegetable and also as salads or may even be used to prepare stews, soups and sauces or it could be eaten with yam or plantain. It turns out to be a very good source of dietary fibre, manganese, copper, vitamin B6. Folate, magnesium and niacin (Sanchez-Mata et.al., 2010). Aubergine also contains phytochemical nutrients such as nasunin and chlorogenic acid which are antioxidants that protect neutral cell membranes and enhance the brain to function (Oguntona, 1998). Garden egg supplements starch food (Kochhar, 1981; Hui, 2006).

Eggplants have indigenous medicinal uses which range from weight reduction to treatment of several ailments including asthma, skin infection and constipation (Safowora, 1993). They are very beneficial in control of hypertension and diabetes, and enhancement of antioxidant and anticancer activities in the body. According to American Diabetes Association (2009) eggplant can be used to manage degenerative conditions of the body such as elevated blood sugar and increased weight gain. This property is due to its high content of polyphenols authenticated by a study carried out by Nwannaet.al (2019).

In addition, a research carried out by Anosikeet.al, in 2012 showed anti-inflammatory activity of garden eggs. The green and the white fruit are consumed fresh and served to visitors as kola in homes (Tindal, 1965). Eggplant leaves are vegetables that are useful in traditional medicine (Akindahunsi and Salawu 2005). There are about 1,500 species of genus-Solanum. Despite the numerous uses of aubergine, the nutrient compositions have not been fully established.

The aim of this study, therefore, is to determine the proximate compositions, (moisture, fat, ash, protein, crude fibre and carbohydrate contents), mineral, and vitamin contents of fruits of four different cultivars of the egg plant, namely, Solanum anguivi, S. aethiopicum (gilo group), $S$. macrocarpon and S. aethiopicum (kumba group).

\section{MATERIALS AND METHODS}

\section{Sample Procurement, Identification and preparation}

The fruits of the four cultivars of egg plant (Solanum melongena): (i) Solanum anguivi, (ii) $S$. aethiopicum (gilo group), (iii) S. macrocarpon and (iv) S. aethiopicum (kumba group) - were purchased from Eke-ukwu market in Owerri, Imo State, Nigeria and identified in the Department of Plant Science and Biotechnology of Imo State University, Owerri. The fruits were then sorted, trimmed, washed and allowed to drain dry. They were then sliced into $1 \mathrm{~cm}$ thick with a sharp knife. The slices were then put in forced draughed oven (model 200) and dried to constant weight and the moisture content determined (AOAC, 2012). After the moisture content determination, the dry slices were then ground in a blender and stored for further analysis.

\section{Proximate Analysis}

The fat, protein, ash, crude fibre and carbohydrate contents were determined by the standard AOAC (2012) methods.

Journal of the Faculty of Agriculture and Veterinary Medicine, Imo State University Owerri website: www ajol.info; Attribution: Non-commercial CC BY-NC: CC-BY-NC 
Volume 18, Number 2, October 2020, pp $135-142$

\section{Determination of Micronutrients}

Micronutrients were determined as described by Onwuaka (2018)

\section{Determination of calcium, magnesium and iron contents}

One gram of each sample was put into a digestion flask and $20 \mathrm{ml}$ of acid mixture $(650 \mathrm{ml}$ conc $\mathrm{HNO}_{3} ; 80 \mathrm{ml}$ perchloric acid PCA and $20 \mathrm{ml} \mathrm{Conc} \mathrm{H}_{2} \mathrm{SO}_{4}$ ) were added. The flask was heated until a clear digest was obtained; the digest was diluted with distilled water to the $500 \mathrm{ml}$ volumetric flask mark. Appropriate dilutions were then made for each element for calcium and magnesium, $\mathrm{S}_{\mathrm{r}} \mathrm{Cl}_{2}$ solution containing $10,000 \mathrm{mg} / \mathrm{ml}$ to yield a $1,500 \mathrm{mg} / \mathrm{ml}$ of $\mathrm{Sr}^{2+}$ in the final solution. Calibration curves were prepared for each element using standard solutions. The appropriate lamp and correct wavelength for each element was specified on the instruction manual of the Atomic absorption spectrophotometer instrument.

\section{Determination of vitamin $\mathbf{C}$ content}

Ten grammes $(10 \mathrm{~g})$ of the blended sample were homogenized with an extracting solution containing metaphosphoric acid and acetic acid. The mixture was placed in a conical flask and agitated at $10,000 \mathrm{rpm}$ for $15 \mathrm{~min}$. The mixture was then filtered through a whatman filter paper. The ascorbic acid standard was prepared by dissolving $100 \mathrm{mg}$ of L-ascorbic acid in a metaphosphoric acid / acetic acid solution at a final concentration of $0.1 \mathrm{mg} / \mathrm{ml}$. Quantification of vitamin C content was performed using an Agilent HPLC (High performance liquid chromatography) with a U.V absorbance at $254 \mathrm{~nm}$ at room temperature.

\section{Determination of Vitamin A content}

Ten grammes $(10 \mathrm{~g})$ of the blended sample, one gramme $(1 \mathrm{~g})$ of pyrogallic acid, $70 \mathrm{ml}$ ethanol, and 30rnl (50\%) of potassium hydroxide were added, and reflushed for 40min using a water bath at $50 \pm 2{ }^{\circ} \mathrm{C}$. Extracts were obtained three times using various ether concentrations $(50 \mathrm{~m} 1,30 \mathrm{ml}$ and $20 \mathrm{~m} 1$ ). Distilled water was used to neutralize the extract, which wasdehydrated using anhydrous sodium sulphate. Further, the extracts were put in the water bath at a temperature of $50 \pm 2^{\circ} \mathrm{C}$, diluted to $10 \mathrm{ml}$ by using methanol, filtered using a $0.45 \mathrm{~nm}$ membrane and finally subjected to High Performance Liquid Chromatography (HPLC) analysis at $265 \mathrm{~nm} \mathrm{U.V}$ absorbance.

\section{Statistical Analysis}

The raw data were subjected to statistical Analysis using Analysis of Variance (ANOVA). Tukey's test was used to separate the means. 
Volume 18, Number 2, October 2020, pp $135-142$

\section{RESULTS}

\section{Proximate Compositions of the Four Cultivars of Aubergine}

The results of the proximate analyses of the four cultivar samples of eggplant namely; Solanum anguivi, Solanum aethiopicum (gilo group), Solanum macrocarpon and Solanum aethiopicum (kumba group) are presented in Table 1.

\subsection{Micronutrient Compositions}

The results of the micronutrients content determination of the four cultivars of eggplant are presented in Table 2 .

\section{DISCUSSION}

\section{Proximate Compositions}

The results of the analyses presented in Table 1 show the proximate compositions of the four cultivars of eggplant. Solanumaethiopicum (gilo group) had the highest moisture content (90.63 \pm 1.13 ) followed by S. anguivi $(88.21 \pm 0.5 \%)$ S. eathiopicum (kumba group) had $(85.33 \pm 0.20 \%)$ while $S$. macrocarpon had the least moisture content of $(80.29 \pm 1.46 \%)$. There was no significant difference ( $\mathrm{p} \unlhd \mathbf{0 . 0 5}$ ) in moisture content among the cultivars. Chinedu et.al (2011) reported some values of two cultivars of eggplant in which moisture contents were $89.27 \pm 0.12 \%$ for $S$. aethiopicumand $92.50 \pm 0.14$ for $S$. macrocarpon. High moisture content implieslow value for the total solid that makes up the fruit. The high moisture content of these varieties ought to make them susceptible to infection by micro-organisms, however, the fibrous nature of their skin makes it a little bit difficult for micro-organisms to penetrate, thus tends to extend the shelf life of the eggplant.

In fat content, $S$. macrocarpon had the highest $(4.00 \pm 0.4 \%)$ followed by S. aethiopicum (kumba

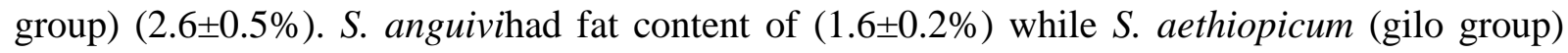
had the least $(1.4 \pm 0.25 \%)$. There was also no significant difference in fat content among the four cultivars. They are ideal fruits for individuals susceptible to obesity, serum lipid levels, high blood pressure and other related heart diseases, American Diabetes Association (2009). The ash content is an indication of the mineral content; S. anguivi had the highest ash content of $0.76 \pm 0.33 \%$ followed by $S$. aethiopicum. (gilo group) with $0.62 \pm 0.01 \%, S$. aethiopicum (kumba group) $0.54 \pm .60 \%$ while $S$. macrocarpum had the least value of $0.52 \pm 0.02 \%$. There were also no significant differences among the ash contents of the cultivars. Agoreyo and Oghene (2011) reported some values which show $1.96 \pm 0.12 \%$ for S. aethiopicum, (gilo group) and $3.15 \pm 0.13 \%$ for $S$. macrocarpon. Values reported were higher than those obtained from this study.

The protein contents of the four varieties respectively were, S. anguivi $3.94 \pm 0.45 \%, S$. aethiopicum, gilo group $4.38 \pm 0.3 \%$, S. macrocarpon $8.31 \pm 0.68$ and S. aethiopicum; kumbagroup $5.69 \pm 0.02$. The protein contents of $S$. anguiviand $S$. aethiopicum (gilo group) were significantly Journal of the Faculty of Agriculture and Veterinary Medicine, Imo State University Owerri website: www ajol.info; Attribution: Non-commercial CC BY-NC: CC-BY-NC 
different from those of $S$. macrocarpum and $S$. aethiopicum (kumba group). HoweverS. macrocarpon had the highest protein content. The values obtained are within the range of vegetable and fruits (Ball, 1998). Proteins are known to be good polymers of amino acids. Agoreyo and Oghene, (2011) reported some values of two varieties having protein contents of $5.79 \pm 0.22 \%$ and $4.58 \pm 0.46$ respectively, which were within the values obtained.

Their carbohydrate contents were $2.63 \pm 0.07 \%$ for $S$. anguivi, $0.47 \pm 0.29 \%$ for S. aethiopicum; (gilo group), S. macrocarpon $4.86 \pm 0.48 \%$ and $3.82 \pm 0.22 \%$ for $S$. aethiopicum; (kumba group). S. aethiopicum (kumba group) had the highest while $S$. aethiopicum (gilo group) had the least. There were significant differences in carbohydrate content among the cultivars. Generally, all the 4 cultivars had very low carbohydrate contents

The crude fibre values obtained included $2.86 \pm 0.12 \%$ for $S$. anguivi, (the highest), $2.50 \pm 0.03$ for S. aethiopicum; (gilo group) $2.02 \pm 0.08$ for $S$. macrocarpon and also $2.02 \pm 0.08$ for $S$. aethiopicum (the least). There was no significant difference among the values ( $\mathrm{p} \searrow 0.05)$. Chinedu et.al (2011) reported some values which did not deviate so much from the above values.

In all, Nwannaet.al. (2013) reported values of moisture, protein, crude fibre and ash contents of Solanum aethiopicum which are in agreement with the values obtained in this study.

\section{Micronutrient Compositions}

The results of the micronutrient content determination of the four cultivars of eggplant presented in Table 2 show that $S$. anguivihad the greatest amount of vitamin A (528.06 iu/ $/ \mathrm{kg})$, calcium, (586.02 ppm), Magnesium, (106.31 ppm) and Iron (14.97ppm), but the least amount of vitamin C $(108.65 \mathrm{mg} / 100 \mathrm{~g})$. Micronutrients are needed by the human body in very small quantities (generally less than $100 \mathrm{mg} /$ day) as opposed to macronutrients which are needed or required in very large quantities. The result revealed that there was no significant difference among the samples except in the vitamin C contents: there was significant difference between vitamin $\mathrm{C}$ contents of S. anguivi, S. aethiopicum (gilo group) and those of S. macrocarpon. These findings did not deviate much from those of Bello et.al. (2008).

\section{CONCLUSION}

The study has demonstrated that all the four cultivars of the egg plant contain substantial amounts of moisture, protein, ash, crude fibre and micronutrients; however, carbohydrate and fat contents were low. The Solanum macrocarpon cultivar contained the highest amount of protein and carbohydrate while Solanum auguivi contained the highest amount of crude fibre and minerals. Solanum anguivi cultivar is therefore the most highly recommended out of the four cultivars. 


\section{REFERENCES}

Anosike, C., Onyeche, O., Lawrence U. and Ezeanyika S. (2012). The anti-inflammatory activity of garden egg (Solanum aethiopicum) on egg albumin induced oedema and granuloma tissue formation in rats Asian Pacific Journal of Tropical Medicine 5(1): 62-66. https://doi.org/10.1016/S1995-7645(11)60247-2

Agoreyo, B.O. and Oghene O.A. (2011) Changes in the Glucose level of Eggplant spps. during ripening J. Med. Biomedical 10: 6 - 12 .

Akindahunsi, A.A. and Salawu, S.O. (2005) Phytochemical Screening and Nutrient Composition of Selected Tropical Green Leafy Vegetables. African J. Biotechnol 4: 497 - 501.

American Diabetes Association (2009) Diagnosis and Classification of Diabetes Mellitus Diabetes Care 32:562-567

AOAC (2012) Official Methods of Analysis (19 ${ }^{\text {th }}$ Ed.) Association of Analytical chemists, Washington D.C.

Ball, J.M. (1998) Preliminary report of a survey of user Requirement for New Pacific Food Tables. South Pacific, Commission Nouman. New Caledonia p. 50.

Bello, M.O., Folade O.S., Adewusi S.R.V. and Olawore S. (2008) Studies on the chemical compositions and anti-nutrients of some lesser known Nigerian Fruits. African $J$. Biotechnol7: 3972 - 3979.

Chinedu, S.N., Olasumbo A.C.; Eboji O.K.; Emiloku, O.C., Arinola, O.K. and Dania D. (2011) Proximate and Phytochemical Analyses of Solanum aethiopicum and S. macrocarpon L. fruits. Research J. Chem. Sci 1(3): 63 - 71.

Hui, Y.H. (2006) Hand Book of Food Science and Technology and Engineering. C.R.C. Press London. pp 13-20.

Kochhar, S.L. (1981) Tropical Crops, A textbook of Botany Macmillan Press Ltd. London. pp 50 -60 .

Nwanna, E.E., Ibukun, E. O. and Oboh, G. (2013) Nutritional contents and antioxidants activities of African garden egg (Solanum aethiopicum) cultivars Advanced Food Science 35: 1-6.

Nwanna, E.E., Ibukun, E. O. and Oboh, G. (2019) Nutritional Content of selected species of tropical eggplant fruit (Solanumspp) diet Attenuates nepatic inflammation in high-fat fed male Wistar rats induced with streptozotocin Food Sci. Nutr7: 109-119. https://doi.org/10.1002/fsn3.811

Oguntona, T. (1998) Green Leafy Vegetables. J. Nutr. Quality of Plant Foods 2: 120 - 123.

Onimawo, I.A. (2002) Proximate composition and selected physiochemical properties of seed pulp, J. Plant Nutr. 57:165-171. https://doi.org/10.1023/A:1015228231512

Journal of the Faculty of Agriculture and Veterinary Medicine, Imo State University Owerri website: www ajol.info; Attribution: Non-commercial CC BY-NC: CC-BY-NC 
Onwuka, G.I. (2018). Food Analysis and Instrumentation Theory and Practice. Naphthali Prints. Lagos - Nigeria pp $301-342$.

Safowora, A. (1993). Medicinal Plants and Traditional Medicine in Africa. Spectrum Books Ltd. Ibadan. pp $191-289$.

Sanchez - Mata, N.C., Yokoyama, W.E., Hong Y.Y. and Prohens, J. (2010). “ $\alpha$ solasonine and $\alpha$ - solamargine content of Gboma (solanum macrocarpon L.) and scarlet (Solanum aethiopicum, L.) Eggplants Agric. Food chem. 59(9)503-550. https://doi.org/10.1021/jf100709g

Tindal, H.O. (1965) Fruits and vegetables in West Africa. (2 ${ }^{\text {nd }}$ Ed.) Oxford University Press. London. 5(8): 105. 


\section{APPENDIX}

Table 1: Proximate compositions of the four cultivars of eggplant

\begin{tabular}{lllll}
\hline \multicolumn{5}{c}{ Samples } \\
Nutrients (\%) & A & B & C & D \\
\hline Moisture & $88.21 \pm 0.52^{\mathrm{a}}$ & $90.63 \pm 1.13^{\mathrm{a}}$ & $80.29 \pm 1.46^{\mathrm{a}}$ & $85.33 \pm 0.20^{\mathrm{a}}$ \\
Fat & $1.60 \pm 0.20^{\mathrm{a}}$ & $1.40 \pm 0.25^{\mathrm{a}}$ & $4.00 \pm 0.40^{\mathrm{a}}$ & $2.60 \pm 0.50^{\mathrm{a}}$ \\
Ash & $0.76 \pm 0.03^{\mathrm{a}}$ & $0.62 \pm 0.01^{\mathrm{a}}$ & $0.52 \pm 0.02^{\mathrm{a}}$ & $0.54 \pm 0.60^{\mathrm{a}}$ \\
Protein & $3.94 \pm 0.41^{\mathrm{c}}$ & $4.38 \pm 0.30^{\mathrm{bc}}$ & $8.31 \pm 0.68^{\mathrm{a}}$ & $5.69 \pm 0.02^{\mathrm{b}}$ \\
Crude Fibre & $2.86 \pm 0.12^{\mathrm{a}}$ & $2.50 \pm 0.03^{\mathrm{a}}$ & $2.02 \pm 0.08^{\mathrm{a}}$ & $2.02 \pm 0.08^{\mathrm{a}}$ \\
Carbohydrate & $2.63 \pm 0.07^{\mathrm{c}}$ & $0.47 \pm 0.29^{\mathrm{d}}$ & $4.86 \pm 0.48^{\mathrm{a}}$ & $3.82 \pm 0.22^{\mathrm{b}}$ \\
\hline
\end{tabular}

Key:

$$
\begin{aligned}
\text { Sample A } & =\text { Solanum anguivi } \\
\mathrm{B} & =S . \text { aethiopicum (Gilo group) } \\
\mathrm{C} & =S . \text { macrocarpon } \\
\mathrm{D} & =S . \text { aethiopicum (Kumba group) }
\end{aligned}
$$

Values are means \pm SD

Values with different superscripts along the same row show significant differences among them.

Table 2: Micronutrients Compositions of the eggplant cultivars

$$
\text { Samples }
$$

\begin{tabular}{lllll} 
Micro-nutrients & A & B & C & D \\
& & & & \\
\hline Vitamin A (iu) & $528.06 \pm 26.39^{\mathrm{a}}$ & $475.18 \pm 0.05^{\mathrm{a}}$ & $449.82 \pm 12.73^{\mathrm{a}}$ & $448.06 \pm 13.61^{\mathrm{a}}$ \\
Vitamin C (mg/100g) & $108.65 \pm 678.77^{\mathrm{b}}$ & $447.85 \pm 509.17^{\mathrm{b}}$ & $2929.65 \pm 731.74^{\mathrm{a}}$ & $2378.57 \pm 456.20^{\mathrm{a}}$ \\
calcium (ppm) & $586.02 \pm 160.40^{\mathrm{a}}$ & $241.55 \pm 11.84^{\mathrm{a}}$ & $135.36 \pm 64.93^{\mathrm{a}}$ & $97.95 \pm 83.64^{\mathrm{a}}$ \\
Magnesium (ppm) & $106.31 \pm 8.53^{\mathrm{a}}$ & $80.63 \pm 4.31^{\mathrm{a}}$ & $82.66 \pm 3.30^{\mathrm{a}}$ & $87.40 \pm 0.93^{\mathrm{a}}$ \\
Iron (ppm) & $14.97 \pm 1.75^{\mathrm{a}}$ & $10.38 \pm 0.55^{\mathrm{a}}$ & $10.14 \pm 0.67^{\mathrm{a}}$ & $10.40 \pm 0.54^{\mathrm{a}}$ \\
\hline
\end{tabular}

Key: $\quad$ Sample A = Solanum anguivi

$$
\begin{aligned}
& \mathrm{B}=S . \text { aethiopicum (Gilo group) } \\
& \mathrm{C}=S . \text { macrocarpon } \\
& \mathrm{D}=S . \text { aethiopicum (Kumba group) }
\end{aligned}
$$

Values are means $\pm \mathrm{SD}$

Values along the same row with the same superscript are not significantly different from each other.

Journal of the Faculty of Agriculture and Veterinary Medicine, Imo State University Owerri website: www ajol.info; Attribution: Non-commercial CC BY-NC: CC-BY-NC 